Article

\title{
Effect of Chitosan-Ascorbic Acid Coatings on the Refrigerated Storage Stability of Fresh-Cut Apples
}

\author{
Kübra Sultan Özdemir ${ }^{1,2}$ and Vural Gökmen ${ }^{1, *}$ \\ 1 Food Quality and Safety (FoQuS) Research Group, Department of Food Engineering, Hacettepe University, \\ Beytepe Campus, 06800 Ankara, Turkey \\ 2 Department of Food Engineering, Faculty of Engineering and Architecture, Konya Food and Agriculture \\ University, 42080 Meram, Konya, Turkey \\ * Correspondence: vgokmen@hacettepe.edu.tr; Tel.: +90-312-297-7108; Fax: +90-312-2992123
}

Received: 15 July 2019; Accepted: 7 August 2019; Published: 8 August 2019

\begin{abstract}
Using natural antimicrobial substances in edible films becomes crucial to extend the shelf-life of fresh-cut fruits due to the consumers' preferences. In this study chitosan and ascorbic acid based film was used to improve the shelf-life of fresh-cut apples. Fresh-cut apple cubes were dipped in water (control), ascorbic acid (1\%) or mixtures of chitosan-ascorbic acid in different ratios ( $1 \%: 1 \%$, $2 \%: 2 \%$ or $1 \%: 5 \%$ ) for $5 \mathrm{~min}$. After draining, fresh-cut apples were packed in sterile polypropylene jars and stored at $5{ }^{\circ} \mathrm{C}$ for 14 days. The treatment with chitosan and ascorbic acid suppressed browning, retained flesh firmness and maintained phenolic compounds throughout the storage period. Moreover, the treatment with chitosan-ascorbic acid significantly retarded the microbial growth during storage. Those findings suggested that the best performance was acquired in $1 \%$ chitosan and 5\% ascorbic acid coating. That coating could be practical and useful to prolonging the chemical and microbial shelf lives of fresh-cut apples during refrigerated storage.
\end{abstract}

Keywords: fresh-cut apples; refrigerated storage; shelf-life; chitosan; ascorbic acid; coating; Gompertz model

\section{Introduction}

Apple (Malus domestica) is an important-and one of the most widely consumed-fruits in the world, due to its health benefits. Apples contain significant amount of minerals, dietary fibers and polyphenols which are related to prevention of diseases, such as coronary diseases [1]. Polyphenols especially are related to the nutritional value, flavor and color of apple products. They can vary depending on the apple type [2]. The major polyphenols of apple can be listed as flavan-3-ols (catechin, epicatechin), flavanols (quercetin) dihydrochalcones, hydroxycinnamic acids (chlorogenic acid), and anthocyanins [3]. In recent years, the increasing demand of consumers for healthy fast and easily accessible foods, caused a strong increase in prepacked 'ready-to-eat' produce consumption [4]. Among those foods, fresh-cut apples have an important economic value in that market due to their low cost, convenience and popularity. However, microbial growth and browning reactions limit their shelf-life. Fresh cut apples are subject to enzymatic browning, due to the action of polyphenol oxidase on phenolic compounds. Browning causes undesired changes in appearance, flavor and nutrient composition [5]. The common approach to control/prevention of the browning in fresh-cut products is to use anti-browning agents [6]. Carboxylic acids, ascorbic acid derivatives, sulfur containing amino acids and phenolic acids can be used effectively as anti-browning agents to delay enzymatic browning in apples $[7,8]$.

Many strategies have been developed for the preservation of, and increasing the quality of, fresh-cut and minimally processed fruits and vegetables. These include the use of modified atmosphere 
packaging [8], chemical treatments [9], thermal treatments [10], edible coatings [11-13] and hurdle technologies [12,14]. Among these methods, edible coatings have been recently gained more interest than others in food preservation. Edible films and coatings are natural polymers which control moisture transfer, gas exchange, respiration and oxidative reaction rates during handling, storage and transportation of the fresh produce $[15,16]$. Carbohydrates, proteins, gums, lipids or starch-based edible films can be used as a coating material for fresh-cut products.

Chitosan is a carbohydrate-based biopolymer. It is an amino polysaccharide composed of randomly distributed $\beta$-(1-4)-linked D-glucosamine and $N$-acetyl-D-glucosamine units [17-19]. Chitosan based edible films and coatings have great potential in the preservation of fruit and vegetables [20-22]. Chitosan and its derivatives have an ability to inhibit the growth of yeasts, molds and bacteria [23-25]. However, the application of chitosan is limited due to its insolubility at neutral $\mathrm{pH}$ [26]. To overcome this disadvantage and to improve solubility of chitosan, different acids were used to decrease $\mathrm{pH}$ values below $\mathrm{pH} 6$ to improve chitosan solubility [16,21,27-29].

Qi et al. 2011 [30] studied the effect of chitosan, ascorbic acid and calcium chloride on fresh-cut fuji apples. They used citric acid to dissolve chitosan and prepared film solutions by adding calcium chloride and ascorbic acid. They have found out that coatings effectively retarded enzymatic browning during storage at $5{ }^{\circ} \mathrm{C}$ for 8 days, and apple slices with chitosan-coating maintained firmness with a little loss during storage. In another study, calcium chloride-chitosan coatings and chitosan-ascorbic acid coatings during storage at room temperature for $10 \mathrm{~h}$ were investigated [31]. Calcium treatments (calcium chloride or lactate) are broadly studied in preserving the quality of fresh-cut fruit and vegatables. There are many reports about the positive effects of calcium on fresh-cut texture and browning [32]. This study aims to use a binary aqueous mixture of chitosan and ascorbic acid as a coating to improve the refrigerated storage stability of fresh-cut apple cubes. Contrary to other studies mentioned above, we used solely ascorbic acid instead of other organic acids (i.e., acetic acid) to dissolve chitosan in water. Lowering $\mathrm{pH}$ by means of adding ascorbic acid helped chitosan molecules to dissolve readily in water. In addition, ascorbic acid acted as anti-browning agent in the coating mixture. In this context, different combinations of chitosan and ascorbic acid were prepared and used to coat fresh-cut apples. The effects of different coatings were evaulated by monitoring the microbial growth, browning, polyphenol composition and firmness of fresh-cut apples during 14 days of storage at $5{ }^{\circ} \mathrm{C}$. In addition, the kinetics of the growths of yeasts and molds, psychrophilic and mesophilic bacteria in fresh-cut apple samples with different coatings during storage were analyzed by using the Gompertz model.

\section{Materials and Methods}

\subsection{Chemicals and Consumables}

Ascorbic acid, chitosan (from crab shells, degree of deacetylation of $75-85 \%$ and medium molecular weight), ethanol (HPLC grade), acetonitrile (HPLC grade), chlorogenic acid (5-Caffeoylquinic acid), (+)-catechin, and (-) epicatechin were purchased from Sigma-Aldrich (Steinheim, Germany). Plate count agar (PCA), potato dextrose agar (PDA) and formic acid (98\%) were obtained from Merck Co. (Darmstadt, Germany).

Ultra-pure water was used throughout the phenolic composition analysis (Milli Q-System, Millipore, Milford, MA, USA). Syringe filters (nylon, $0.45 \mu \mathrm{m}$ ) were supplied from Waters (Millford, MA). A HICHROM 5C $18(250 \times 4.6 \mathrm{~mm}$, Hichrom, Reading, UK) column was used for analysis of phenolic compounds.

\subsection{Preparation of Fresh-Cut Apples and Dipping Solutions}

Apples (Granny Smith) were obtained from a local market at commercial maturity. Uniformly sized apples were selected and any bruised or diseased fruits were discarded. The selected apples 
were rinsed gently with tap water and drained at room temperature. Then apples were cut into about $1 \mathrm{~cm}^{3}$ cubes with a stainless-steel knife.

Fresh-cut apples were dipped into water (control), aqueous ascorbic acid solution (1\%ASC) or the mixtures of chitosan-ascorbic acid. The concentrations of chitosan and ascorbic acid were varied from 1 to $2 \%$ and from 1 to $5 \%$, respectively, in three mixtures. In the first mixture, $1 \mathrm{~g}$ of ascorbic acid was dissolved in water and $1 \mathrm{~g}$ of chitosan was added to the solution $(1 \% \mathrm{CH}-1 \% \mathrm{ASC})$. In the second mixture, $5 \mathrm{~g}$ of ascorbic acid was dissolved in water and $1 \mathrm{~g}$ of chitosan was added to the solution ( $1 \% \mathrm{CH}-5 \% \mathrm{ASC}$ ). In the third mixture, $2 \mathrm{~g}$ of ascorbic acid was dissolved in water and $2 \mathrm{~g}$ of chitosan was added to the solution ( $2 \% \mathrm{CH}-2 \%$ ASC). Ultrasonification was applied after magnetic stirring to achieve complete dissolution of $\mathrm{CH}$. $\mathrm{pH}$ values of solutions were measured by using a $\mathrm{pH}$-meter at room temperature.

\subsection{Treatments of Fresh-Cut Apples}

Fresh-cut apple cubes were grouped into five and the treatments were applied. Each group (50 g) were dipped in $100 \mathrm{~mL}$ of solution or mixture for each time. After the application, the coated apples were left to surface dry (at about $25^{\circ} \mathrm{C}$ and with a relative humidity of $30 \%$ during $1 \mathrm{~h}$ ) until excess coating solution was gone. A total of 27 packages (six for microbiological, three for weight loss, and 18 for physical and chemical analyses) were prepared for each treatment. Apple samples of $10 \mathrm{~g}$ were placed into sterile polypropylene jars $(30 \mathrm{~mL})$. Biaxially oriented polypropylene (BOPP) film (thickness of $30 \mu \mathrm{m}$ and $\mathrm{O}_{2}$ permeability of $1600 \mathrm{~cm}^{3} \cdot \mathrm{m}^{-2}$ per day) were used for covering the packages. All samples were stored at $5 \pm 1{ }^{\circ} \mathrm{C}$ at $90-95 \%$ relative humidity for 14 days and samples were taken after $0,3,7$ and 14 days of storage. Concentrations of phenolic compounds were determined at 0,6 , 12 and 18 days of storage.

\subsection{Microbiological Analyses and Kinetic Modelling of Microbial Growth}

The growth of microbial population in coated fresh-cut apples throughout storage was evaluated by counting total yeasts and molds, total aerobic mesophilic bacteria and psychrophilic bacteria. Apple samples of $10 \mathrm{~g}$ were taken aseptically from each jar and transferred into sterile plastic bags. Samples were diluted with $90 \mathrm{~mL}$ of saline water and homogenized for $2 \mathrm{~min}$ in a stomacher blender.

Serial dilutions were made and then poured onto the PCA for total aerobic mesophilic counts (TAC) and psychrophilic counts. TAC plates were incubated at $35^{\circ} \mathrm{C}$ for $48 \mathrm{~h}$, and to determine psychrophilic counts, plates were incubated at $5^{\circ} \mathrm{C}$ for $10-15$ days. Yeast and mold counts were performed on PDA by using the spread plate method by incubating at $25^{\circ} \mathrm{C}$ for $5-7$ days. Colonies were counted and the results were given as $\log _{10} \mathrm{CFU} \cdot \mathrm{g}^{-1}$ of apples. Two replicate counts were performed for each sample. Moreover, the Gompertz equation modified by Zwietering et al.(1990) [33], was used to describe the microbial data from each application and given in Equation (1):

$$
\log _{10}\left(\frac{N}{N_{0}}\right)=A \exp \left(-\exp \left(\frac{\mu_{m} e}{A}(\lambda-t)+1\right)\right)
$$

where $N$ is the number of microorganisms at time $t$ (day), $N_{0}$ is initial number of microorganisms, $\mu_{\mathrm{m}}$ is the maximum growth rate, $\lambda$ is the lag time (day), $A$ is the maximum population density and $t$ is the time (day). The experimental data were fitted by using Matlab version 9.2.

\subsection{Measurement of Weight Loss}

Fresh-cut apples were weighed at the end of days 0, 3, 7 and 14. Measurements were replicated three times. Considering of the initial and final weights of fresh-cut apples, weight loss was determined as expressed in Equation (2):

$$
\text { Weight loss }(\%)=\frac{\left(m_{t}-m_{0}\right)}{m_{0}} \times 100
$$


where $m_{0}$ is the initial weight of fresh-cut apples and $m_{t}$ is the weight of sample at time $t$.

\subsection{Measurement of Firmness}

Firmness of fresh-cut apples was determined by using TA Plus texture analyzer (LLYOD Instruments, AMETEK Co. Ltd., Shanghai, China) with a $5 \mathrm{~mm}$ diameter cylindrical probe. The required force $(\mathrm{N})$ to puncture the samples was recorded as firmness. Measurements were replicated six times.

\subsection{Measurement of Color}

For the effect of coatings on color, browning index (BI) values were calculated by using computer-vision based image analyses. Apple cubes were photographed from $25 \mathrm{~cm}$ height above the sample by a digital camera (Canon, Japan) in a box. Two light sources (Ultrabright, $6500 \mathrm{~K}, 25 \mathrm{~W}$ ) were placed at a $45^{\circ}$ angle to the sample. The percentage of dark areas was calculated by segmentation method given by Gökmen and Mogol (2010) and data were given as browning index [34].

\subsection{Analysis of Phenolic Compounds}

One gram of apple sample was homogenized in $5 \mathrm{~mL}$ of the mixture of ethanol and water (50:50, $v / v$ ) containing $500 \mathrm{mg} / \mathrm{L}$ ascorbic acid. After centrifugation $(6080 \mathrm{~g}$ for $5 \mathrm{~min}$ ) supernatants were separated in a test tube. Polyphenol analyses were performed on an Agilent $1200 \mathrm{LC}$ system equipped with an Agilent 6130 MS detector. Chromatographic separation was performed on a HICHROM 5 C18 column at $30^{\circ} \mathrm{C}$ according to the method given by Ozdemir et al. [35]. Solution A was $1.0 \%$ formic acid in water and solution was B 1.0\% formic acid in acetonitrile. The gradient profile was as following: 0-8 min linear gradient elution from 10 to $30 \%$ of $\mathrm{B} ; 10-12$ min linear gradient elution from 30 to $10 \%$ $\mathrm{B}$; and $12-20 \mathrm{~min}$; isocratic elution of $10 \% \mathrm{~B}$. For analysis, $10 \mu \mathrm{L}$ of sample was injected and the flow rate was $0.7 \mathrm{~mL} / \mathrm{min}$. An electrospray ionization source was used and the phenolic compounds were analyzed in negative and positive modes. The following MS conditions were adjusted: Positive scan mode of capillary voltage $4.0 \mathrm{kV}$; negative scan mode of capillary voltage $3.5 \mathrm{kV}$; drying gas $\left(\mathrm{N}_{2}\right)$ flow of $13 \mathrm{~L} / \mathrm{min}$ at $325^{\circ} \mathrm{C}$; nebulizer pressure of $40 \mathrm{psi}$; negative and positive ion scanning modes from 50 to $1000 \mathrm{~m} / \mathrm{z}$. Phenolic compounds were identified by comparing the retention times of unknown peaks with the retention times of standard compounds.

\subsection{Statistical Analysis}

The results were given as mean \pm standard deviations. Differences were determined by analysis of variance (ANOVA) followed by Duncan's multiple range test $(p<0.05)$. Independent sample $t$ testing was carried out to compared the means of two independent samples. For the statistical analyses, SPSS 18.0 version (SPSS Inc., Chicago, IL, USA) was used.

\section{Results and Discussion}

\subsection{Weight Loss}

The weight of coated fresh-cut apples was monitored to determine the efficiency of these coatings during storage time in terms of keeping the moisture. It was known that weight loss in fresh-cut fruits is related to the loss of water caused by transpiration and loss of carbon reserves due to the respiration processes [36]. The weight losses of coated samples with $1 \% \mathrm{CH}-1 \% \mathrm{ASC}$ and $1 \% \mathrm{CH}-5 \% \mathrm{ASC}$ were significantly lower than those of the control and 1\% ASC treated apples at the end of storage $(p<0.05)$ (Table 1). The highest weight loss was determined in 1\% ASC coated apples. Furthermore, $1 \% \mathrm{CH}-1 \% \mathrm{ASC}$ coating showed the best performance on inhibition of water loss by showing the lowest weight loss at the end of storage. 
Table 1. Changes in the weight loss (\%) values of fresh cut apples during storage at $5{ }^{\circ} \mathrm{C}$.

\begin{tabular}{cccc}
\hline \multirow{2}{*}{ Treatment } & \multicolumn{3}{c}{ Storage Time (day) } \\
\cline { 2 - 4 } & $\mathbf{3}$ & $\mathbf{7}$ & $\mathbf{1 4}$ \\
\hline Control & $0.47 \pm 0.08^{\mathrm{aA}}$ & $0.55 \pm 0.23^{\mathrm{aAB}}$ & $3.45 \pm 0.40^{\mathrm{bC}}$ \\
$1 \%$ ASC & $0.45 \pm 0.01^{\mathrm{aA}}$ & $0.31 \pm 0.02^{\mathrm{aA}}$ & $5.38 \pm 0.39 \mathrm{bD}$ \\
$1 \% \mathrm{CH}-1 \%$ ASC & $1.04 \pm 0.12^{\mathrm{aB}}$ & $1.00 \pm 0.24^{\mathrm{aB}}$ & $1.31 \pm 0.26^{\mathrm{aA}}$ \\
$1 \% \mathrm{CH}-5 \%$ ASC & $0.94 \pm 0.26^{\mathrm{aB}}$ & $0.92 \pm 0.31^{\mathrm{aB}}$ & $2.11 \pm 0.72^{\mathrm{aAB}}$ \\
$2 \% \mathrm{CH}-2 \% A S C$ & $0.87 \pm 0.04^{\mathrm{aB}}$ & $1.65 \pm 0.18^{\mathrm{bC}}$ & $2.63 \pm 0.33^{\mathrm{cBC}}$ \\
\hline
\end{tabular}

* Values were presented in mean \pm standard deviation $(n=3)$. Different lowercase and uppercase letters indicate significance at $\alpha=0.05$ in the same row and column, respectively.

This result was related to the formation of a layer of chitosan around the surface of fruit. This layer slowed down the respiration rate of the fruit and retarded the loss of water. Our results supported by other studies revealed that chitosan coating reduced weight loss in fruits and vegetables, such as mango fruit [28], bell pepper, cucumber [37] and litchi [38].

\subsection{Firmness}

In the present study, the firmness of the control, \%1ASC and $1 \% \mathrm{CH}-1 \% \mathrm{ASC}$ treated apples did not significantly decrease in the 7 days of storage but after 14 days, data could not be obtained due to the substantial softening of apples (Table 2). That softening was related with the action of pectin enzymes in apple samples.

Table 2. Changes in the firmness (N) values of fresh cut apples during storage at $5{ }^{\circ} \mathrm{C}$.

\begin{tabular}{lcccc}
\hline \multirow{2}{*}{ Treatment } & \multicolumn{4}{c}{ Storage Time (Day) } \\
\cline { 2 - 5 } & $\mathbf{1}$ & $\mathbf{3}$ & $\mathbf{7}$ & $\mathbf{1 4}$ \\
\hline Control & $20.2 \pm 2.2^{\mathrm{bA}}$ & $17.6 \pm 0.3^{\mathrm{aA}}$ & $18.6 \pm 1.8^{\mathrm{abA}}$ & - \\
$1 \% A S C$ & $20.9 \pm 1.7^{\mathrm{aA}}$ & $19.6 \pm 2.6^{\mathrm{aA}}$ & $20.8 \pm 1.8^{\mathrm{aA}}$ & - \\
$1 \% \mathrm{CH}-1 \% A S C$ & $20.6 \pm 1.2^{\mathrm{aA}}$ & $19.0 \pm 2.8^{\mathrm{aA}}$ & $19.6 \pm 2.2^{\mathrm{aA}}$ & - \\
$1 \% \mathrm{CH}-5 \% A S C$ & $19.6 \pm 2.1^{\mathrm{aA}}$ & $20.1 \pm 2.3^{\mathrm{aA}}$ & $19.3 \pm 2.3^{\mathrm{aA}}$ & $18.1 \pm 3.5^{\mathrm{aA}}$ \\
$2 \% \mathrm{CH}-2 \% A S C$ & $19.1 \pm 1.7^{\mathrm{aA}}$ & $19.4 \pm 1.9^{\mathrm{aA}}$ & $19.3 \pm 2.4^{\mathrm{aA}}$ & $18.4 \pm 4.6^{\mathrm{aA}}$ \\
\hline
\end{tabular}

* Values were presented in mean \pm standard deviation $(n=6)$. Different lowercase and uppercase letters indicate significance at $\alpha=0.05$ in the same row and column, respectively.

Polygalacturonase enzymes especially, cause changes in texture and loss of firmness of the fruit $[39,40]$. However, firmness of $1 \% \mathrm{CH}-5 \%$ ASC and $2 \% \mathrm{CH}-2 \%$ ASC treated apples remained stable during 14 days of storage. This can be explained with increment in chitosan and ascorbic acid concentrations. $1 \%$ ASC and $1 \% \mathrm{CH}-1 \%$ ASC treated apples lost their textural integrity faster than apples coated with $1 \% \mathrm{CH}-5 \%$ ASC and $2 \% \mathrm{CH}-2 \%$ ASC. Those results are in line with the results obtained by other researchers, which underline the beneficial effects of chitosan toward fruit firmness maintenance $[30,40]$.

\subsection{Color}

Data of browning index (BI) values calculated by using computer-vision based image analyses are given in Figure 1. BI was increased with time during storage at $5{ }^{\circ} \mathrm{C}$ for all applications $(p<0.05)$.

Figure 2 shows the digital color images of fresh-cut apple samples with different treatments. BI increased in control samples immediately after cutting apples, but chitosan-ascorbic coating retarded the browning of the fruit. The browning index increased up to $64 \%$ in control samples and $54 \%$ in $1 \%$ ASC treated samples while it was lower in $1 \% \mathrm{CH}-5 \%$ ASC and $2 \% \mathrm{CH}-2 \%$ ASC coated apples. $\% 1$ ascorbic acid had also a positive effect on the browning ratio but in combination with chitosan, it was more effective over storage time. Although browning occurred in chitosan-ascorbic acid combinations 
at the end of storage, $1 \% \mathrm{CH}-5 \%$ ASC and $2 \% \mathrm{CH}-2 \% \mathrm{ASC}$ coatings retarded the browning in the first three days.

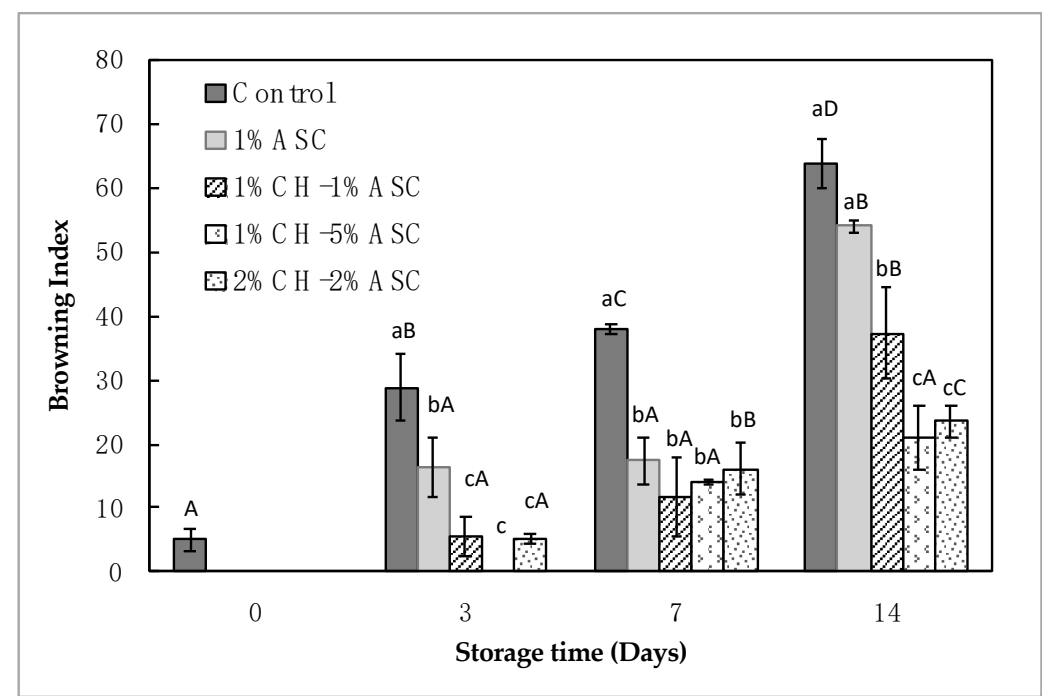

Figure 1. Changes in the browning index (\%) values of fresh cut apple samples during storage at $5{ }^{\circ} \mathrm{C}$. Values are means of two replications. Vertical bars represent standard deviation. Data in the same day with each treatment having different superscript lowercase letters are significantly different $(p<0.05)$. Data on each day of storage in the same treatment having different superscript uppercase letters are significantly different $(p<0.05)$.

Day 0
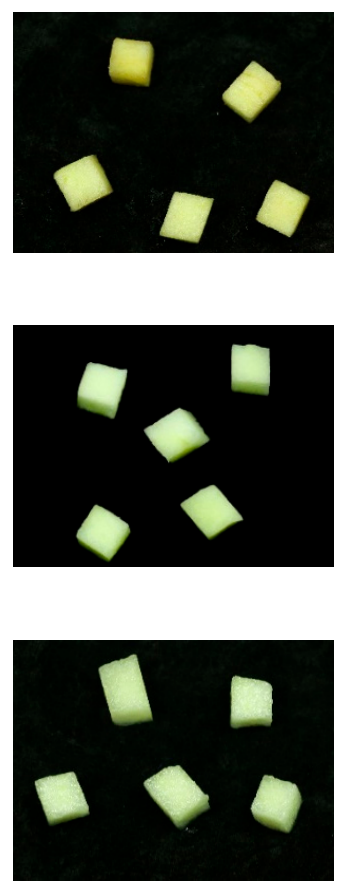

Day 3
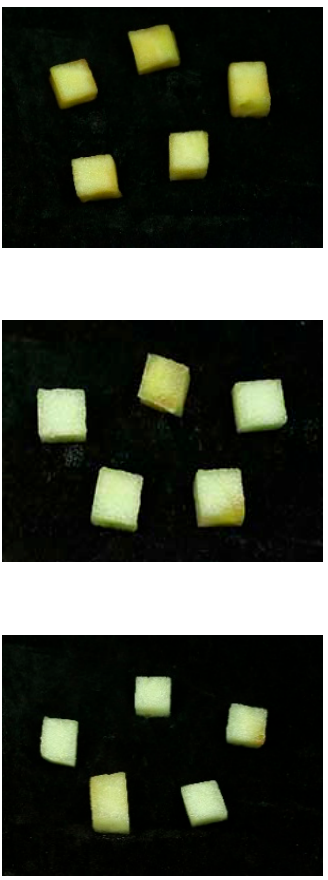

Day 14
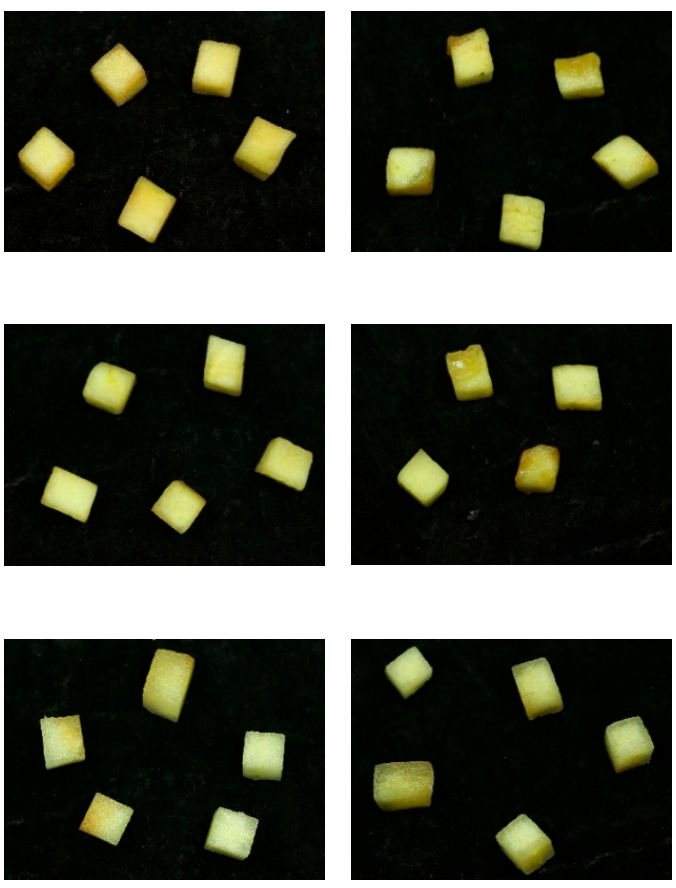

Figure 2. Cont. 

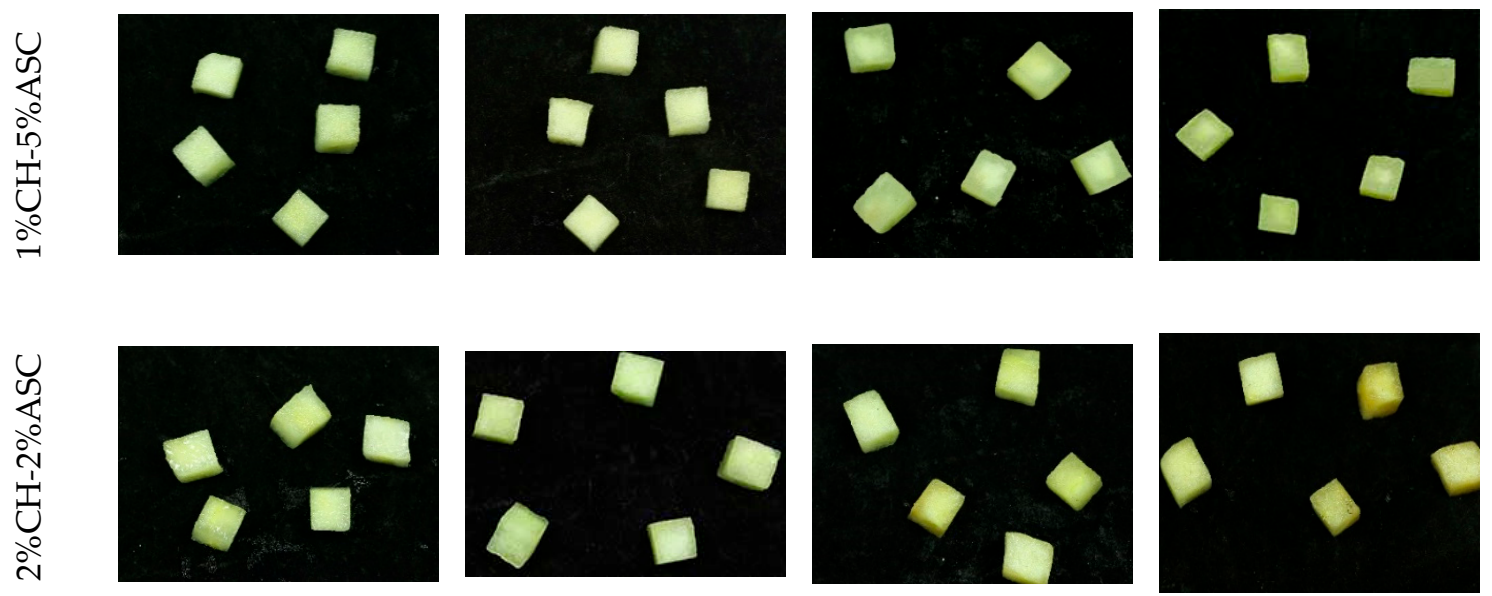

Figure 2. Images of fresh-cut apples after coating and storing at $5^{\circ} \mathrm{C}$ for days $0,3,7$ and 14 .

Chitosan-ascorbic acid coatings inhibited the browning of apple pieces, and browning inhibition was enhanced by increasing the ascorbic acid and chitosan ratio in the solution. These results were also supported by the studies on the beneficial side of chitosan on browning [41-43]. In addition, anti-browning agents such as ascorbic acid and citric acid suppress the polyphenol oxidase activity working as reducing agents [44].

\subsection{Phenolic Compounds}

The most important flavanol compounds in apples, catechin, epicatechin and chlorogenic acid (5-Caffeoylquinic acid), were determined, and concentrations $\left(C / C_{0}\right)$ of those polyphenols were presented in Table 3. Those compounds are strongly related with browning, because they are well-known substrates to the polyphenol oxidase enzyme [45]. The concentrations of epicatechin and catechin in control samples decreased at a ratio of $70 \%$ and $90 \%$, respectively, at the end of storage. However, initial concentrations of catechin and epicatechin could be retained $89 \%$ and $71 \%$, respectively, in the samples coated with the mixture of $\% 1 \mathrm{CH}-5 \%$ ASC (Table 3).

Table 3. Changes in the dimensionless concentrations $\left(C / C_{0}\right)$ of certain phenolic compounds in fresh cut apples during storage at $5{ }^{\circ} \mathrm{C}$.

\begin{tabular}{ccccc}
\hline Analysis & Day & Control & $\mathbf{1 \% C H - 1 \% A S C}$ & $\mathbf{1 \% C H - 5 \% A S C}$ \\
\hline \multirow{3}{*}{ Catechin } & 0 & $1.00 \pm 0.00^{\mathrm{aA}}$ & $1.00 \pm 0.00^{\mathrm{aA}}$ & $1.00 \pm 0.00^{\mathrm{abA}}$ \\
& 6 & $0.17 \pm 0.02^{\mathrm{bA}}$ & $0.80 \pm 0.12^{\mathrm{bB}}$ & $1.17 \pm 0.09^{\mathrm{aC}}$ \\
& 12 & $0.13 \pm 0.01^{\mathrm{bcA}}$ & $0.21 \pm 0.02^{\mathrm{cA}}$ & $0.95 \pm 0.09^{\mathrm{bB}}$ \\
& 18 & $0.10 \pm 0.02^{\mathrm{cA}}$ & $0.20 \pm 0.00^{\mathrm{cA}}$ & $0.89 \pm 0.07^{\mathrm{bB}}$ \\
\hline \multirow{3}{*}{ Epicatechin } & 0 & $1.00 \pm 0.00^{\mathrm{aA}}$ & $1.00 \pm 0.0^{\mathrm{aA}}$ & $1.00 \pm 0.00^{\mathrm{aA}}$ \\
& 6 & $0.35 \pm 0.07^{\mathrm{bcA}}$ & $0.89 \pm 0.09^{\mathrm{aB}}$ & $0.75 \pm 0.11^{\mathrm{abB}}$ \\
& 12 & $0.46 \pm 0.00^{\mathrm{bA}}$ & $0.42 \pm 0.01^{\mathrm{bA}}$ & $0.55 \pm 0.09^{\mathrm{bA}}$ \\
Chlorogenic acid & 18 & $0.30 \pm 0.00^{\mathrm{cA}}$ & $0.28 \pm 0.03^{\mathrm{cA}}$ & $0.71 \pm 0.19^{\mathrm{abB}}$ \\
& 0 & $1.00 \pm 0.00^{\mathrm{aA}}$ & $1.00 \pm 0.00^{\mathrm{aA}}$ & $1.00 \pm 0.00^{\mathrm{aA}}$ \\
& 6 & $0.93 \pm 0.00^{\mathrm{aA}}$ & $1.05 \pm 0.11^{\mathrm{aA}}$ & $1.06 \pm 0.02^{\mathrm{aA}}$ \\
& 12 & $0.99 \pm 0.08^{\mathrm{aA}}$ & $1.30 \pm 0.04^{\mathrm{aAB}}$ & $0.82 \pm 0.01^{\mathrm{bBC}}$ \\
& 18 & $1.06 \pm 0.07^{\mathrm{aA}}$ & $1.12 \pm 0.04^{\mathrm{aA}}$ & $0.91 \pm 0.13^{\mathrm{abA}}$ \\
\hline
\end{tabular}

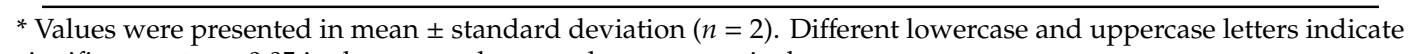
significance at $\alpha=0.05$ in the same column and row, respectively.

Chlorogenic acid was not significantly affected $(p>0.05)$ by the storage period for all applications (Table 3). According to the results the best application to retain polyphenol content in apples was $1 \%$ chitosan and 5\% ascorbic acid formulation. Ascorbic acid treatment combined with chitosan preserved polyphenol content to maintain the same levels as the first day. Moreover, increasing the ascorbic 
acid proportion from $1 \%$ to $5 \%$ in the coating solution was more effective for maintaining phenolic compounds. Similarly, ascorbic acid with carboxymethyl cellulose coating maintained phenolic compounds in fresh-cut apple slices [7]. It has been reported that ascorbic acid ensures protection by its oxygen scavenger property and avoiding polyphenol oxidase-catalyzed reactions [46].

\subsection{Microbialanalyses and Shelf Life Modelling}

In the first day of storage, in all samples, total aerobic mesophilic bacteria, total yeasts and molds were found to be below the detectable amount. In the control sample and 1\% ASC treated sample, the number of total yeasts and molds was determined as $6.5 \pm 0.4 \log \mathrm{cfu} / \mathrm{g}$ and $6.9 \pm 0.2 \mathrm{log} \mathrm{cfu} / \mathrm{g}$ at the end of storage, respectively (Table 4). To evaluate the results on Table $4, \mathrm{pH}$ values of coating solutions were also measured and determined as: Control solution: $6.80 ; 1 \% \mathrm{CH}-1 \% \mathrm{ASC}$ : $4.42 ; 2 \% \mathrm{CH}-2 \% \mathrm{ASC}$ : 4.45; $1 \% \mathrm{CH}-5 \%$ ASC: $3.31 ; 1 \%$ ascorbic acid: 2.92 ; all at room temperature. Cadogan et al. 2014 investigated the effect of solvents on antibacterial activity of chitosan membranes. They showed that the chitosan dissolved in ascorbic acid had higher antimicrobial activity than the chitosan dissolved in citric and maleic acid. This was related with the crosslinking effect of ascorbic acid. Polymer molecules, i.e., chitosan, could have easily penetrated into bacterial cell walls and hence changed the internal $\mathrm{pH}$ of bacteria [47]. In our study, the ratio of chitosan was the same in $1 \% \mathrm{CH}-5 \% \mathrm{ASC}$ and $1 \% \mathrm{CH}-1 \%$ ASC coatings. Their pH levels were 3.31 and 4.45 , respectively. Treatments of $1 \% \mathrm{CH}-5 \%$ ASC showed no yeast and mold growth in day 14 while $3.2 \log$ CFU/g was observed in $1 \% \mathrm{CH}-1 \% \mathrm{ASC}$. This could be related with $\mathrm{pH}$ and crosslinking properties of ascorbic acid. However, the $1 \% \mathrm{CH}-1 \%$ ASC and $2 \% \mathrm{CH}-2 \%$ ASC coatings' $\mathrm{pH}$ levels were 4.42 and 4.45 , yet the antimicrobial activity was higher in $2 \% \mathrm{CH}-2 \% \mathrm{ASC}$. This could be derived from the higher amount of chitosan.

Table 4. Changes in the counts of yeasts and molds, aerobic mesophilic bacteria and psychrophilic bacteria $\left(\log _{10} \mathrm{CFU} / \mathrm{g}\right)$ in fresh-cut apples during storage at $5{ }^{\circ} \mathrm{C}$.

\begin{tabular}{|c|c|c|c|}
\hline Treatment & Day 0 & Day 7 & Day 14 \\
\hline \multicolumn{4}{|c|}{ Yeasts and molds } \\
\hline Control & UDL * & $4.0 \pm 0.2^{* * a A}$ & $6.5 \pm 0.4 \mathrm{aB}$ \\
\hline $1 \%$ ASC & UDL & $5.0 \pm 0.0^{\mathrm{aA}}$ & $6.9 \pm 0.2^{\mathrm{aB}}$ \\
\hline $1 \% \mathrm{CH}-1 \%$ ASC & UDL & $2.5 \pm 0.3^{\mathrm{bA}}$ & $3.2 \pm 0.2^{\mathrm{bA}}$ \\
\hline $2 \% \mathrm{CH}-2 \%$ ASC & UDL & UDL & UDL \\
\hline $1 \% \mathrm{CH}-5 \%$ ASC & UDL & UDL & UDL \\
\hline \multicolumn{4}{|c|}{ Aerobic mesophilic bacteria } \\
\hline Control & UDL & $1.0 \pm 0.0^{\mathrm{A}}$ & $3.1 \pm 0.1^{\mathrm{B}}$ \\
\hline $1 \%$ ASC & UDL & UDL & UDL \\
\hline $1 \% \mathrm{CH}-1 \%$ ASC & UDL & UDL & UDL \\
\hline $2 \% \mathrm{CH}-2 \%$ ASC & UDL & UDL & UDL \\
\hline $1 \% \mathrm{CH}-5 \%$ ASC & UDL & UDL & UDL \\
\hline \multicolumn{4}{|c|}{ Psychrophilic bacteria } \\
\hline Control & $1.0 \pm 0.0^{\mathrm{aA}}$ & $4.0 \pm 0.4 \mathrm{aB}$ & $5.2 \pm 0.1^{\mathrm{aC}}$ \\
\hline $1 \%$ ASC & $1.1 \pm 0.3^{\mathrm{aA}}$ & $4.0 \pm 0.4^{\mathrm{aB}}$ & $5.1 \pm 0.3^{\mathrm{aC}}$ \\
\hline $1 \% \mathrm{CH}-1 \%$ ASC & $1.0 \pm 0.0^{\mathrm{aA}}$ & $1.9 \pm 0.3^{\mathrm{bB}}$ & UDL \\
\hline $2 \% \mathrm{CH}-2 \%$ ASC & $1.2 \pm 0.2^{\mathrm{a}}$ & UDL & UDL \\
\hline $1 \% \mathrm{CH}-5 \%$ ASC & UDL & UDL & UDL \\
\hline
\end{tabular}

* UDL:Under Detection Limit $<1 \log _{10} \mathrm{CFU} / \mathrm{g}{ }^{* *}$ Values were presented in mean \pm standard deviation $(n=4)$. Different lowercase and uppercase letters indicate significance at $\alpha=0.05$ in the same column and row, respectively.

The quantity of aerobic mesophilic bacteria at the end of the storage was $3.1 \log \mathrm{cfu} / \mathrm{g}$ in control samples, while it was found to be below the detectable amount in coated samples. In that situation, it can be said that chitosan film coatings with ascorbic acid reduced or inhibited the total aerobic mesophilic bacteria and total yeasts and molds. The number of total psychrophilic aerobic bacteria were increased in the control and 1\% ASC treated apple samples up to $5.2 \mathrm{log}$ CFU/g at the end of storage, while it was determined below the detectable count in chitosan and ascorbic acid coated 
samples. Also, many researchers determined that chitosan coatings reduce microbial counts in fresh-cut produce [18,48-50].

The microbiological data were described by using the Gompertz equation. The three interpretable parameters defined by the model (maximum growth rate, lag time and maximum population density) are given in Table 5. The model described the growth of yeast and mold counts, as well as those of mesophilic aerobic counts with high determination coefficients $\left(\mathrm{R}^{2}\right)$. The maximum growth rate and maximum population density were highly influenced by the different treatments. The maximum growth rate for yeast and molds were determined as 1.16 and $1.38 \Delta \log _{10}\left(\mathrm{CFU} . \mathrm{g}^{-1}\right) /$ day for control and $1 \%$ ASC treated samples, respectively, while it was 0.49 for $1 \% \mathrm{CH}-1 \%$ ASC coated apples. Those results confirmed the microbiological counts and it was seen that microbial growth was faster in control and $1 \%$ ASC coated samples than other applications. Eventually, maximum growth (A) was higher for yeast and molds in control and 1\%ASC treated apples than that found in $1 \% \mathrm{CH}-1 \% \mathrm{ASC}$ treated apples. That was also related with antimicrobial activity of chitosan.

Table 5. Gompertz model parameters for the growth of yeasts and molds, psychrophilic and mesophilic bacteria in fresh-cut apples during storage at $5{ }^{\circ} \mathrm{C} *$

\begin{tabular}{|c|c|c|c|c|c|}
\hline \multirow{2}{*}{ Population } & \multirow{2}{*}{ Treatments } & \multicolumn{4}{|c|}{ Gompertz Model Parameters } \\
\hline & & $A(\log \mathrm{cfu} / \mathrm{g})$ & $\begin{array}{c}\mu_{\max } \\
(\Delta \log [\mathrm{cfu} / \mathrm{g}] / \text { day })\end{array}$ & $\lambda$ (day) & $\mathbf{R}^{2}$ \\
\hline \multirow{5}{*}{ Yeasts and molds } & Control & $6.63 \pm 0.46$ & $1.16 \pm 0.09$ & $3.52 \pm 0.05$ & 1.00 \\
\hline & $1 \%$ ASC & $6.91 \pm 0.20$ & $1.38 \pm 0.01$ & $3.08 \pm 0.09$ & 1.00 \\
\hline & $1 \% \mathrm{CH}-1 \% \mathrm{ASC}$ & $2.99 \pm 0.42$ & $0.49 \pm 0.07$ & $2.86 \pm 0.70$ & 1.00 \\
\hline & $2 \% \mathrm{CH}-2 \% \mathrm{ASC}$ & - & - & - & - \\
\hline & $1 \% \mathrm{CH}-5 \% \mathrm{ASC}$ & - & - & - & - \\
\hline \multirow{5}{*}{$\begin{array}{c}\text { Mesophilic aerobic } \\
\text { bacteria }\end{array}$} & Control & $3.32 \pm 0.10$ & $0.46 \pm 0.00$ & $4.79 \pm 0.02$ & 1.00 \\
\hline & $1 \%$ ASC & - & - & - & - \\
\hline & $1 \% \mathrm{CH}-1 \% \mathrm{ASC}$ & - & - & - & - \\
\hline & $2 \% \mathrm{CH}-2 \% \mathrm{ASC}$ & - & - & - & - \\
\hline & $1 \% \mathrm{CH}-5 \% \mathrm{ASC}$ & - & - & - & - \\
\hline \multirow{5}{*}{$\begin{array}{l}\text { Psychrophilic } \\
\text { bacteria }\end{array}$} & Control & $4.21 \pm 0.11$ & $0.94 \pm 0.10$ & $3.50 \pm 0.21$ & 1.00 \\
\hline & $1 \%$ ASC & $3.96 \pm 0.04$ & $0.94 \pm 0.20$ & $3.46 \pm 0.63$ & 1.00 \\
\hline & $1 \% \mathrm{CH}-1 \% \mathrm{ASC}$ & - & - & - & - \\
\hline & $2 \% \mathrm{CH}-2 \% \mathrm{ASC}$ & - & - & - & - \\
\hline & $1 \% \mathrm{CH}-5 \%$ ASC & - & - & - & - \\
\hline
\end{tabular}

\section{Conclusions}

The results revealed that coating with chitosan and ascorbic acid was an effective solution for inhibiting the growth of microorganisms, retarding enzymatic browning reactions and reducing the weight loss of fresh-cut apples during refrigerated storage. Increasing the ratio of ascorbic acid in the coatings decreased the browning ratio on fresh-cut apples. From a practical point of view, $1 \%$ chitosan and 5\% ascorbic acid coating successfully extended the cold storage period for 7 days in fresh-cut apples by maintaining the browning level, preserving microbial and chemical quality. The results suggest that coating with chitosan and ascorbic acid can be a viable approach to improve the shelf life of fresh-cut fruits sensitive to microbial and chemical deterioration under refrigerated conditions. Additionally, such an approach could be used in combination with modified atmosphere packaging to further prolong the shelf life.

\section{Patents}

WO2015142303A1: A solution for extending shelf life of ready-to-eat fresh fruits and/or vegetables and an application method thereof 
Author Contributions: Writing—original draft preparation, K.S.Ö.; investigation K.S.Ö, and V.G.; methodology, K.S.Ö, and V.G.; writing-review and editing, V.G.

Funding: This research received no external funding.

Conflicts of Interest: The authors declare no conflict of interest.

\section{References}

1. Marszałek, K.; Woźniak, Ł.; Barba, F.J.; Skapska, S.; Lorenzo, J.M.; Zambon, A.; Spilimbergo, S. Enzymatic, physicochemical, nutritional and phytochemical profile changes of apple (Golden Delicious L.) juice under supercritical carbon dioxide and long-term cold storage. Food Chem. 2018, 268, 279-286. [CrossRef] [PubMed]

2. Li, X.; Wu, X.; Bi, J.; Liu, X.; Li, X.; Guo, C. Polyphenols accumulation effects on surface color variation in apple slices hot air drying process. LWT 2019, 108, 421-428. [CrossRef]

3. Guo, J.; Yue, T.L.; Yuan, Y.H.; Wang, Y.T. Chemometric Classification of Apple Juices According to Variety and Geographical Origin Based on Polyphenolic Profiles. J. Agric. Food Chem. 2013, 61, 6949-6963. [CrossRef] [PubMed]

4. Kabelitz, T.; Hassenberg, K. Control of apple surface microflora for fresh-cut produce by post-harvest hot-water treatment. LWT 2018, 98, 492-499. [CrossRef]

5. Luo, Y.; Barbosa Canovas, G.V. Enzymatic browning and its inhibition in new apple cultivars slices using 4-hexylresorcinol in combination with ascorbic acid. Food Sci. Technol. Int. 1997, 3, 195-201. [CrossRef]

6. Mcevily, A.J.; Iyengar, R.; Otwell, W.S. Inhibition of Enzymatic Browning in Foods and Beverages. Crit. Rev. Food Sci. 1992, 32, 253-273. [CrossRef]

7. Saba, M.K.; Sogvar, O.B. Combination of carboxymethyl cellulose-based coatings with calcium and ascorbic acid impacts in browning and quality of fresh-cut apples. LWT Food Sci. Technol. 2016, 66, 165-171. [CrossRef]

8. Putnik, P.; Kovacevic, D.B.; Herceg, K.; Pavkov, I.; Zoric, Z.; Levaj, B. Effects of modified atmosphere, anti-browning treatments and ultrasound on the polyphenolic stability, antioxidant capacity and microbial growth in fresh-cut apples. J. Food Process. Eng. 2017, 40, e12359. [CrossRef]

9. Oms-Oliu, G.; Aguiló-Aguayo, I.; Martín-Belloso, O. Inhibition of Browning on Fresh-cut Pear Wedges by Natural Compounds. J. Food Sci. 2006, 71, S216-S224. [CrossRef]

10. Terefe, N.S.; Tepper, P.; Ullman, A.; Knoerzer, K.; Juliano, P. High pressure thermal processing of pears: Effect on endogenous enzyme activity and related quality attributes. Innov. Food Sci. Emerg. 2016, 33, 56-66. [CrossRef]

11. Alves, M.M.; Goncalves, M.P.; Rocha, C.M.R. Effect of ferulic acid on the performance of soy protein isolate-based edible coatings applied to fresh-cut apples. LWT Food Sci. Technol. 2017, 80, 409-415. [CrossRef]

12. Sanchis, E.; Ghidelli, C.; Sheth, C.C.; Mateos, M.; Palou, L.; Perez-Gago, M.B. Integration of antimicrobial pectin-based edible coating and active modified atmosphere packaging to preserve the quality and microbial safety of fresh-cut persimmon (Diospyros kaki Thunb. cv. Rojo Brillante). J. Sci. Food Agric. 2017, 97, 252-260. [CrossRef] [PubMed]

13. Marquez, G.R.; Di Pierro, P.; Mariniello, L.; Esposito, M.; Giosafatto, C.V.L.; Porta, R. Fresh-cut fruit and vegetable coatings by transglutaminase-crosslinked whey protein/pectin edible films. LWT Food Sci. Technol. 2017, 75, 124-130. [CrossRef]

14. Moreira, M.R.; Alvarez, M.V.; Martin-Belloso, O.; Soliva-Fortuny, R. Effects of pulsed light treatments and pectin edible coatings on the quality of fresh-cut apples: A hurdle technology approach. J. Sci. Food Agric. 2017, 97, 261-268. [CrossRef] [PubMed]

15. Rojas-Grau, M.A.; Sobrino-Lopez, A.; Tapia, M.S.; Martin-Belloso, O. Browning inhibition in fresh-cut 'fuji' apple slices by natural antibrowning agents. J. Food Sci. 2006, 71, S59-S65. [CrossRef]

16. Park, H.J. Development of advanced edible coatings for fruits. Trends Food Sci. Technol. 1999, 10, $254-260$. [CrossRef]

17. Xia, W.; Liu, P.; Zhang, J.; Chen, J. Biological activities of chitosan and chitooligosaccharides. Food Hydrocoll. 2011, 25, 170-179. [CrossRef]

18. Devlieghere, F.; Vermeulen, A.; Debevere, J. Chitosan: Antimicrobial activity, interactions with food components and applicability as a coating on fruit and vegetables. Food Microbiol. 2004, 21, 703-714. [CrossRef] 
19. Dutta, P.K.; Tripathi, S.; Mehrotra, G.K.; Dutta, J. Perspectives for chitosan based antimicrobial films in food applications. Food Chem. 2009, 114, 1173-1182. [CrossRef]

20. Kerch, G. Chitosan films and coatings prevent losses of fresh fruit nutritional quality: A review. Trends Food Sci. Technol. 2015, 46, 159-166. [CrossRef]

21. Wang, S.Y.; Gao, H. Effect of chitosan-based edible coating on antioxidants, antioxidant enzyme system, and postharvest fruit quality of strawberries (Fragaria x aranassa Duch.). LWT Food Sci. Technol. 2013, 52, 71-79. [CrossRef]

22. Ma, L.; Zhang, M.; Bhandari, B.; Gao, Z.X. Recent developments in novel shelf life extension technologies of fresh-cut fruits and vegetables. Trends Food Sci. Technol. 2017, 64, 23-38. [CrossRef]

23. Coma, V.; Martial-Gros, A.; Garreau, S.; Copinet, A.; Salin, F.; Deschamps, A. Edible Antimicrobial Films Based on Chitosan Matrix. J. Food Sci. 2002, 67, 1162-1169. [CrossRef]

24. Shahidi, F.; Arachchi, J.K.V.; Jeon, Y.-J. Food applications of chitin and chitosans. Trends Food Sci. Technol. 1999, 10, 37-51. [CrossRef]

25. Vásconez, M.B.; Flores, S.K.; Campos, C.A.; Alvarado, J.; Gerschenson, L.N. Antimicrobial activity and physical properties of chitosan-tapioca starch based edible films and coatings. Food Res. Int. 2009, 42, 762-769. [CrossRef]

26. Ge, H.-C.; Luo, D.-K. Preparation of carboxymethyl chitosan in aqueous solution under microwave irradiation. Carbohydr. Res. 2005, 340, 1351-1356. [CrossRef] [PubMed]

27. Chien, P.-J.; Sheu, F.; Yang, F.-H. Effects of edible chitosan coating on quality and shelf life of sliced mango fruit. J. Food Eng. 2007, 78, 225-229. [CrossRef]

28. Jongsri, P.; Wangsomboondee, T.; Rojsitthisak, P.; Seraypheap, K. Effect of molecular weights of chitosan coating on postharvest quality and physicochemical characteristics of mango fruit. LWT Food Sci. Technol. 2016, 73, 28-36. [CrossRef]

29. Tezotto-Uliana, J.V.; Fargoni, G.P.; Geerdink, G.M.; Kluge, R.A. Chitosan applications pre- or postharvest prolong raspberry shelf-life quality. Postharvest Biol. Technol. 2014, 91, 72-77. [CrossRef]

30. Qi, H.P.; Hu, W.Z.; Jiang, A.L.; Tian, M.X.; Li, Y.Q. Extending shelf-life of Fresh-cut 'Fuji' apples with chitosan-coatings. Innov. Food Sci. Emerg. 2011, 12, 62-66. [CrossRef]

31. Liu, X.; Ren, J.; Zhu, Y.; Han, W.; Xuan, H.; Ge, L. The preservation effect of ascorbic acid and calcium chloride modified chitosan coating on fresh-cut apples at room temperature. Coll. Surf. A Physicochem. Eng. Asp. 2016, 502, 102-106. [CrossRef]

32. Ngamchuachit, P.; Sivertsen, H.K.; Mitcham, E.J.; Barrett, D.M. Effectiveness of calcium chloride and calcium lactate on maintenance of textural and sensory qualities of fresh-cut mangos. J. Food Sci. 2014, 79, C786-C794. [CrossRef]

33. Zwietering, M.H.; Jongenburger, I.; Rombouts, F.M.; van't Riet, K. Modeling of the bacterial growth curve. Appl. Environ. Microbiol. 1990, 56, 1875-1881. [PubMed]

34. Gökmen, V.; Mogol, B.A. Computer vision-based image analysis for rapid detection of acrylamide in heated foods. Qual. Assur. Saf. Crop. Foods 2010, 2, 203-207. [CrossRef]

35. Özdemir, K.S.; Yılmaz, C.; Durmaz, G.; Gökmen, V. Hazelnut skin powder: A new brown colored functional ingredient. Food Res. Int. 2014, 65, 291-297. [CrossRef]

36. Zhu, X.; Wang, Q.M.; Cao, J.K.; Jiang, W.B. Effects of chitosan coating on postharvest quality of mango (Mangifera indica L. cv. Tainong) fruits. J. Food Process. Preserv. 2008, 32, 770-784. [CrossRef]

37. Elghaouth, A.; Arul, J.; Ponnampalam, R.; Boulet, M. Use of Chitosan Coating to Reduce Water-Loss and Maintain Quality of Cucumber and Bell Pepper Fruits. J. Food Process. Preserv. 1991, 15, 359-368.

38. Dong, H.Q.; Cheng, L.Y.; Tan, J.H.; Zheng, K.W.; Jiang, Y.M. Effects of chitosan coating on quality and shelf life of peeled litchi fruit. J. Food Eng. 2004, 64, 355-358. [CrossRef]

39. Raybaudi-Massilia, R.M.; Mosqueda-Melgar, J.; Sobrino-López, A.; Soliva-Fortuny, R.; Martín-Belloso, O. Shelf-life extension of fresh-cut "Fuji" apples at different ripeness stages using natural substances. Postharvest Biol. Technol. 2007, 45, 265-275. [CrossRef]

40. Hong, K.Q.; Xie, J.H.; Zhang, L.B.; Sun, D.Q.; Gong, D.Q. Effects of chitosan coating on postharvest life and quality of guava (Psidium guajava L.) fruit during cold storage. Sci. Hortic. 2012, 144, 172-178. [CrossRef]

41. Hosseini, M.S.; Zahedi, S.M.; Abadía, J.; Karimi, M. Effects of postharvest treatments with chitosan and putrescine to maintain quality and extend shelf-life of two banana cultivars. Food Sci. Nutr. 2018, 6, 1328-1337. [CrossRef] [PubMed] 
42. Gao, P.; Zhu, Z.; Zhang, P. Effects of chitosan-glucose complex coating on postharvest quality and shelf life of table grapes. Carbohydr. Polym. 2013, 95, 371-378. [CrossRef] [PubMed]

43. Carvalho, R.L.; Cabral, M.F.; Germano, T.A.; de Carvalho, W.M.; Brasil, I.M.; Gallão, M.I.; Moura, C.F.H.; Lopes, M.M.A.; de Miranda, M.R.A. Chitosan coating with trans-cinnamaldehyde improves structural integrity and antioxidant metabolism of fresh-cut melon. Postharvest Biol. Technol. 2016, 113, 29-39. [CrossRef]

44. Ali, H.M.; El-Gizawy, A.M.; El-Bassiouny, R.E.I.; Saleh, M.A. Browning inhibition mechanisms by cysteine, ascorbic acid and citric acid, and identifying PPO-catechol-cysteine reaction products. J. Food Sci. Technol. 2015, 52, 3651-3659. [CrossRef] [PubMed]

45. Oszmianski, J.; Lee, C.Y. Enzymic oxidative reaction of catechin and chlorogenic acid in a model system. J. Agric. Food Chem. 1990, 38, 1202-1204. [CrossRef]

46. Rico, D.; Martín-Diana, A.B.; Barat, J.M.; Barry-Ryan, C. Extending and measuring the quality of fresh-cut fruit and vegetables: A review. Trends Food Sci. Technol. 2007, 18, 373-386. [CrossRef]

47. Cadogan, E.I.; Lee, C.-H.; Popuri, S.R.; Lin, H.-Y. Effect of Solvent on Physico-Chemical Properties and Antibacterial Activity of Chitosan Membranes. Int. J. Polym. Mater. Polym. Biomater. 2014, 63, 708-715. [CrossRef]

48. Alvarez, M.V.; Ponce, A.G.; Moreira, M.D. Antimicrobial efficiency of chitosan coating enriched with bioactive compounds to improve the safety of fresh cut broccoli. LWT Food Sci. Technol. 2013, 50, 78-87. [CrossRef]

49. Karagoz, S.; Demirdoven, A. Effect of chitosan coatings with and without Stevia rebaudiana and modified atmosphere packaging on quality of cold stored fresh-cut apples. LWT Food Sci. Technol. 2019, 108, 332-337. [CrossRef]

50. Pushkala, R.; Parvathy, K.R.; Srividya, N. Chitosan powder coating, a novel simple technique for enhancement of shelf life quality of carrot shreds stored in macro perforated LDPE packs. Innov. Food Sci. Emerg. Technol. 2012, 16, 11-20. [CrossRef]

(C) 2019 by the authors. Licensee MDPI, Basel, Switzerland. This article is an open access article distributed under the terms and conditions of the Creative Commons Attribution (CC BY) license (http://creativecommons.org/licenses/by/4.0/). 